\title{
Could biological invasion by Cryptostegia madagascariensis alter the composition of the arbuscular mycorrhizal fungal community in semi-arid Brazil?
}

Tancredo Augusto Feitosa de Souza ${ }^{*}$, Susana Rodriguez-Echeverria ${ }^{2}$, Leonaldo Alves de Andrade' and Helena Freitas ${ }^{2}$

Received: July 19, 2015

Accepted: November 20, 2015

\begin{abstract}
Biological invasions pose a serious threat to native semi-arid areas of Brazil, especially in areas of the state of Ceará that are typically invaded by Cryptostegia madagascariensis, an exotic plant species from Madagascar. However, how this biological invasion influences the composition of the arbuscular mycorrhizal fungal (AMF) community and how this affects further invasion by C. madagascariensis is not well known. Here we tested how inoculation with species of AMF affects the development of this invasive plant. We analyzed and compared the AMF community composition of four different stages of biological invasion by C. madagascariensis, and examined the effects of inoculation with these four AMF communities, plus a dominant AMF species (Rhizoglomus intraradices) on plant dry biomass, root colonization, plant phosphorous concentration, and plant responsiveness to mycorrhizas of plants of $C$. madagascariensis. We found that all studied treatments (except the inoculum from the native plant root zone) promoted the growth of $C$. madagascariensis and lead to a higher $\mathrm{P}$ concentration. Our results demonstrate that the invader might be altering the composition of the AMF community in field conditions, because inoculation with this community enhanced invader growth, root colonization, and P uptake.
\end{abstract}

Keywords: AMF inoculation, biological invasion, drylands, Glomeromycota, Rhizoglomus intraradices.

\section{Introduction}

To understand more about the effects of invasion on arbuscular mycorrhizal fungi (AMF) community, current research has focused on feedback between AMF communities and invasive species (Zhang et al. 2010), in the host-fungal pairing (Klironomos 2003), and how AMF can impact the performance of invasive species (Stampe \& Daehler 2003). This work is the first field study to examine the impacts of $C$. madagascariensis on AMF community composition along an invasion gradient and to investigate how the changed-AMF community may contribute to create a "window of opportunity" (Johnstone 1986; Agrawal et al. 2005) and consequently influencing plant invasions (Blumenthal 2005; Kulmatiski \& Kardol 2008).

Plant-AMF specificity affects plant invasion (Mummey \& Rillig 2006; Parkash \& Aggarwal 2009; Zhang et al. 2010) and may in some cases strengthen invasive ability of plants through complex feedback loops (Richardson et al. 2000). Plants provide AMF with energy while AMF provides water and nutrients such as phosphorus and nitrogen to the plant host (Smith \& Read 2008; Hodge \& Storer 2014). Plants have affected the AMF community structure through influences on soil resource availability, like available P (Alguacil et al. 2012; Ji et al. 2012; Beauregard et al. 2013; Lekberg et al. 2013; Geel et al. 2015;

\footnotetext{
${ }^{1}$ Centro de Ciências Agrárias, Departamento de Solos e Engenharia Rural, Universidade Federal da Paraíba, 58397-000 Areia, Paraíba, Brazil

${ }^{2}$ Centre for Functional Ecology, Departament of Life Sciences. University of Coimbra, 3000-456 Coimbra, Portugal

* Corresponding author: tancredo_agro@hotmail.com
} 
Wang et al. 2015), and these microorganisms influence plant community composition and ecosystem function (Heijden et al. 2008).

AMF benefit plants by mediating the availability of important plant nutrients (Smith \& Read 2008; Hodge \& Storer 2014), promote plant growth and offer protection against drought and soil pathogens (Rodríguez-Echeverría et al. 2009; Grümberg et al. 2015; Ortiz et al. 2015). We examined the AMF community from Cryptostegia madagascariensis root zone, and compared it with the AMF community from Copernicia prunifera root zone.

In Ceará State, Brazil, the exotic species C. madagascariensis occupies dense areas, occurring widespread and destructive form on native vegetation, particularly C. prunifera, because the exotic species can strangle and kill the palm tree by climbing over it and completely eliminating access to light (Sousa et al. 2013), suggesting that this native plant may be competitively affected by $C$. madagascariensis in the field conditions.

Cryptostegia madagascariensis is a woody-perennial vine that is native to south-west Madagascar. It has been introduced in many Brazilian States by man because of its attractive flowers (Silva et al. 2008). This invasive plant forms dense aboveground stands, suggesting that it exerts a large impact on the AMF community. We studied this alien species into Copernicia forest areas ("Matas de Carnaúba") in Ceará State, Brazil where this species is expanding its range, and the edge of this range is a dangerous invasion front.

Copernicia palm is highly important to local economy of Ceará State, popularly known as the "Tree of life" used in a wide variety of applications (civil construction, craftwork, animal feed and pharmaceutical industry) (DS Pereira et al. 2014). Many programs of development of seedling production have been done, encouragement of tree planting and preservation of Copernicia forest areas have become important; however, C. madagascariensis is capable of invading this environment, thus, threatening native endemic biodiversity.

Thus, we designed a sampling strategy to study how C. madagascariensis invasion alters arbuscular mycorrhizal fungi community composition of the Copernicia Forest, Ceará State, Brazil and hypothesized that (1) C. madagascariensis invasion alters AMF community composition and soil properties, like soil $\mathrm{pH}$ and total organic carbon in the Copernicia Forest; (2) Changed-AMF community can promote the invasive growth; and (3) C. madagascariensis plants can experience a strong relationship with dominant AMF species (Rhizoglomus intraradices in our case). We based these hypotheses on (a) enhanced mutualisms hypothesis proposed by Richardson et al. (2000) and Reinhart \& Callaway (2006); (b) the invasion opportunity windows hypothesis proposed by Johnstone (1986) and Agrawal et al. (2005); (c) the resource-enemy release hypothesis proposed by Blumenthal (2005); and (d) the disturbance- contingent niche creation model proposed by Kulmatiski \& Kardol (2008).

\section{Materials and Methods}

\section{Site description and sampling methods}

We selected study areas near Ibaretama, Ceará, Brazil (06 51'11.3'S, 35 55'51.5'W, and average altitude $109 \mathrm{~m}$ ). The climatic conditions of studied areas is Bsh (Köppen), hot semi-arid with hot summers and mild to warm winters, annual precipitation and temperature of $600 \mathrm{~mm}$ and $30^{\circ} \mathrm{C}$ respectively. Rainfall in these sites is scanty, unpredictable and irregular (Alves et al. 2009). The soil type was classified as an Eutric Vertisol (WRB 2006).

The invasive Cryptostegia madagascariensis Bojer ex. Decne. and the native Copernicia prunifera (Mill.) H. E. Moore, which co-occur in the "Copernicia forest" in the Brazilian xeric shrubland from Ceará State, Brazil, were selected. The seeds of the invader were collected directly from the studied areas.

We collected samples from the root zone of both plants in four different stages of biological invasion by C. madagascariensis: Exotic - areas that contains only C. madagascariensis plants (We collected samples from root zone of young plants with an average height between 0.5 and $0.9 \mathrm{~m}$ ); Native - areas that contains only $C$. prunifera plants (We collected samples from root zone of plants with an estimated average height of $12.0 \mathrm{~m}$ ); Invasive Stage 1 (Invasive1) - areas that contains C. madagascariensis plants (We collected samples from root zone of plants with an average height between 1.5 and $3.0 \mathrm{~m}$ ) climbing over $C$. prunifera plants with an estimated average height of 10.0 $\mathrm{m}$; and Invasive Stage 2 (Invasive2) - areas that contains C. madagascariensis plants (We collected samples from root zone of plants with undetermined average height) climbing over dead C. prunifera plants with an estimated average height of $8.0 \mathrm{~m}$ ).

We established for each stage of biological invasion (four stages - Native, Exotic, Invasive1, Invasive2) by C. madagascariensis forty plots of $100 \mathrm{~m}^{2}$ according to Fortin \& Dale (2005). We collected samples from forty plants in each plot that were pooled within each plot. We selected plants with the following characteristics: plant with diameter near soil surface $>3 \mathrm{~cm}$ and without any individual from a different plant species at a distance lower than $3 \mathrm{~m}$ to the sampling point (Daubenmire 1968; Fortin \& Dale 2005; Caifa \& Martins 2007; Costa \& Araújo 2007; Durigan 2009).

Root zone samples (including soil and root fragments) were collected out near the drip line and beyond $(0-20 \mathrm{~cm}$ deep), at the beginning of September 2012 during the dry period. The root zone samples from each species in each plot were bulked, mixed and stored at $4^{\circ} \mathrm{C}$ until host-plant 
bioassays. Thus, we analyzed 40 composite samples for each invasion stage $(\mathrm{N}=160,40$ composite samples $\mathrm{x}$ four stages). The sampling period was done during the dry season because fungal sporulation is expected to be higher at this time in semi-arid environments (Silva et al. 2014). The root zone samples collected from the field was divided into portions intended for: chemical soil characterization, AMF community assessment, and mounting trap cultures.

For chemical characterization we analyzed soil $\mathrm{pH}$, total organic carbon, total nitrogen and available phosphorus from field soil. Soil $\mathrm{pH}$ was measured in a suspension of soil and distilled water (1:2.5 v:v, soil: water suspension) (Black 1965). Total organic carbon was estimated according methodology described by Okalebo et al. (1993). For nitrogen, the soil samples were digested and total nitrogen was quantified according to Kjeldahl (Black 1965). Available phosphorus (Olsen's $\mathrm{P}$ ) was determined colorimetrically on spectrophotometer at $882 \mathrm{~nm}$ by extraction with sodium bicarbonate for $30 \mathrm{~min}$ (Olsen et al. 1954).

AMF communities were selected from each studied biological invasion stage. These communities naturally exist in the root zone of both studied model plants, where we classified as a changed-AMF community the community of arbuscular mycorrhizal fungi from Exotic, Invasive1 and Invasive 2 areas; and as an unaltered-AMF community the community of AMF from Native areas. So, a trap culture of each AMF community for each condition was established from field soil $(500 \mathrm{~g})$ in plastic pots $(2 \mathrm{~kg})$.

The AMF communities of trap cultures were propagated on a common host-plant (Zea mays L.). This species is a standard host-plant used for mycorrhiza trap cultures and inoculum potential assays according to INVAM (http://invam.caf.wvu.edu/). The plants were grown in sterilized sand: field soil (3:1 $\mathrm{m}: \mathrm{m})$ in a greenhouse condition at University of Coimbra for four months until sporulation. The host-plants received weekly amounts of a modified nutrient solution (Hoagland \& Arnon 1939) containing (in $\mathrm{mg} \mathrm{L}^{-1}$ ): $554.0 \mathrm{KCl}, 200.0 \mathrm{NaH}_{2} \mathrm{PO}_{4}$. $\mathrm{H}_{2} \mathrm{O}, 2.24 \mathrm{MgSO}_{4}, 520.0 \mathrm{CaCl}_{2} \cdot \mathrm{H}_{2} \mathrm{O}, 1.7 \mathrm{MnSO}_{4}, 0.25$ $\mathrm{CuSO}_{4} \cdot 5 \mathrm{H}_{2} \mathrm{O}, 0.30 \mathrm{ZnSO}_{4} \cdot 7 \mathrm{H}_{2} 0,5.0 \mathrm{NaCl}, 3.0 \mathrm{H}_{3} \mathrm{O}_{3}, 0.09$ $\left(\mathrm{NH}_{4}\right) 6 \mathrm{Mo}_{7} \mathrm{O}_{24} \cdot 4 \mathrm{H}_{2} \mathrm{O}$, and $32.9 \mathrm{Na}-\mathrm{Fe}$ EDTA. A portion of soil (500 g) from each studied condition was then used to create the initial AMF-inoculum (The soil, roots, and spores were used as inoculum) used for the experiment with $C$. madagascariensis plants. Another portion of soil $(100 \mathrm{~g})$ was taken from each studied condition for spore extraction and subsequent identification of AMF species for evaluation of the ecological index. The average temperature in the greenhouse was $28^{\circ} \mathrm{C}$, ranging from $20^{\circ} \mathrm{C}$ to $35^{\circ} \mathrm{C}$, an irradiance of up to $70 \%$ of full sun, relative humidity ranging from 65 to $75 \%$, and photoperiod of 16:8 h L:D.

Spores were extracted by the wet sieving technique (Gerdemann \& Nicolson 1963) followed by sucrose centrifugation (Jenkins 1964). Initially, extracted spores were examined in water under a dissecting microscope. They were separated based on morphological characteristics. After it, they were mounted in polyvinyl alcohol lacto-glycerol (PVLG) with or without addition of Melzer's reagent (Walker et al. 2007). The identification of species was based on the descriptions provided by Schenck \& Perez (1990), publications with descriptions of new genera and families (i.e. Oehl et al. 2008), and by consulting the international culture collection of arbuscular mycorrhizal fungi database - INVAM (http://invam.caf.wvu.edu). In this work we adopted the classification proposed by Oehl et al. (2011), including recently described new taxa (i.e. Goto et al. 2012 and Sieverding et al. 2014). After AMF species identification, provide directly from field, we calculated the following ecological index: diversity index $(\mathrm{H})$ proposed by Shannon \& Weaver (1949), and dominance index (C) proposed by Simpson (1949) for each studied AMF community. In addition, we assessed spore abundance (total number of spores), spore abundance of AMF species (number of spores of each AMF species recorded), and the species occurrence frequency $\left(F O_{i}\right)$ of each AMF species. $\mathrm{FO}_{i}$ was calculated using the following equation: $F O_{i}=\mathrm{n}_{\mathrm{i}} / \mathrm{N}$, where $\mathrm{n}_{\mathrm{i}}$ is the number of times an AMF species was observed and $\mathrm{N}$ is the total of AMF spores observed from each stage of invasion. We classify the results of $\mathrm{FO} i$ based on the Zhang's frequency of occurrence classification: dominant $\left(F O_{i}>50 \%\right)$, most common $\left(31 \leq F O_{i} \leq 50 \%\right)$, common $\left(10 \leq F O_{i} \leq 30 \%\right)$ and rare $\left(F O_{i}<10 \%\right)$ (Zhang et al. 2004). The AMF species were also classified as generalists (present in all areas), intermediate (present in three or two areas) or exclusive (present in only one area) (Stürmer \& Siqueira 2011).

The bioassay experiments involved a completely randomized design with six treatments: non-inoculation (Control) and five inoculation treatments with inoculum of AMF communities from: Native = Inoculum from C. prunifera areas; Exotic $=$ Inoculum from $C$. madagas cariensis areas; Invasive1 $=$ Inoculum from Invasive Stage 1 areas (beginning of invasion); Invasive2 = Inoculum from Invasive Stage 2 areas (invasion successful); and inoculum composed by Rhizoglomus intraradices (N.C. Schenck \& G.S. Sm.) Sieverd. G.A. Silva \& Oehl (Rhi), which we found as a dominant AMF species into changed-AMF communities from Exotic, Invasive1, and Invasive2 areas. The control received $500 \mathrm{ml}$ of filtrate from $500 \mathrm{~g}$ of AMF-inoculum with no mycorrhizal spores obtained by sieving through a $25 \mu \mathrm{m}$ mesh, and $500 \mathrm{~g}$ of sterilized mixed AMF-inoculum (a mix of all AMF-inoculums by model plant), thereby controlling for potential mineral and non-mycorrhizal microbial components of the AMF-inoculum. Each treatment had 30 replicates that were coming from 30 independent replicates at trap culture stage.

The experiment was also conducted in a greenhouse at University of Coimbra with average temperatures of 25/16 ${ }^{\circ} \mathrm{C}$ (day/night). Seeds of $C$. madagascariensis were surface 
sterilized in $10 \%$ sodium hypochlorite for 10 minutes, and then thoroughly rinsed with deionized water. Seeds were then were germinated in trays containing autoclaved sand (Twice at $121^{\circ} \mathrm{C}$ for twenty minutes in two consecutive days). Seven days after emergence, seedlings (plant height varying $2-4 \mathrm{~cm}$ ) were selected and individually transferred to plastics pots containing $2000 \mathrm{~g}$ of substrate $(1500 \mathrm{~g}$ of autoclaved sand mixed with $500 \mathrm{~g}$ of soil containing AMF-inoculum, with the number of infective propagules per gram of soil ranging between 5.35 and 6.18. The number of infective propagules was determined following the protocol described by Habte \& Osorio (2001). All pots were covered with aluminum wrap around the seedling to prevent dehydration and external contamination, and the plants were watered with tap water as necessary and fertilized with the same nutrient solution used on trap culture (Hoagland \& Arnon 1939).

Five months after planting, the plants were harvested. Roots were separated from shoots, and immediately the fresh roots were weighed. A total of $0.5 \mathrm{~g}$ of each fresh root sample was used for determination of root colonization. The remaining material and shoots were oven-dried $\left(72^{\circ} \mathrm{C}\right.$ for $48 \mathrm{~h}$ ) and used for measurement of shoot-, and root dry biomass. The amount of colonization was estimated using a grid line intersect method with examination of 100 intersects under a compound microscope at 200X magnification (Phillips \& Hayman 1970; Giovannetti \& Mosse 1980).

The plant responsiveness to mycorrhizas (PRM) was calculated using dry biomass of plants in the AMF-inoculum treatment and the control (Janos et al. 2007), using the formula: $\mathrm{PRM}=\left[\left(\mathrm{B}_{\mathrm{AMF}}-\mathrm{B}_{\text {control }}\right) / \mathrm{B}_{\mathrm{AMF}}\right] \times 100$, where $\mathrm{B}_{\mathrm{AMF}}$ is dry biomass of model plants in the AMF-inoculum treatment and $\mathrm{B}_{\text {control }}$ is dry biomass of the control treatment.

A known mass of the grounded material was digested in a digestion flask containing a triple acid mixture $\left[\mathrm{HNO}_{3}: \mathrm{H}_{2} \mathrm{SO}_{4}: \mathrm{HCl}(60 \%)\right.$, with a ratio of $10: 1: 4$, respectively] to analyze the total $\mathrm{P}$. Phosphorous was analyzed using the vanadate molybdate colorimetric method (Jackson 1973). We also calculated the AMF inoculum effect on plant $\mathrm{P}$ content (IEP), using the formula: IEP = $\left(\mathrm{P}_{\text {AMF }}-\mathrm{P}_{\text {Control }}\right) /\left(\mathrm{P}_{\text {AMF }}+\mathrm{P}_{\text {Control }}\right)$, where $\mathrm{P}_{\text {AMF }}$ is plant $\mathrm{P}$ content in AMF inoculum treatment (adapted from Armas et al. 2005), assuring that the AMF inoculum effect can only range from -1 to +1 , with positive values indicating positive effects of AMF on plant $P$ content, and negative values indicating negative effects.

The relationships between the AMF community structure and soil properties were examined using correlation analyses by the Pearson correlation coefficient $(r)$. Oneway ANOVA was used to test the effect of AMF inoculum on plant dry biomass, and plant $\mathrm{P}$ content for $C$. madagascariensis plants. Data sets were transformed (arcsin square root for percentage variables and logarithmic for other variables), but the results were presented in their original scale of measurement (means with stander deviation) (Zar 1984). For mycorrhizal colonization, PRM and IEP, the Control treatments were excluded from the analyses since the results were null, and were analyzed using Tukey's HSD post-hoc comparison test $(\mathrm{p}<0.05)$. Significant differences among AMF inoculum treatment on plant dry biomass and plant $\mathrm{P}$ content were also determined using the Tukey's HSD post-hoc comparison test $(\mathrm{p}<0.05)$. One way ANOVA and correlation analyses were conducted using SAS 9.1.3 Portable and the ecological indexes were conducted using MVSP 3.1 (Kovach 2007).

\section{Results}

\section{AMF community and soil properties from field samples}

The samples from Exotic and Native areas had the largest number of AMF identified species, with 16.80 and 16.00 identified species respectively, followed by Invasive 1 (11.70) and Invasive2 (8.50). The number of spores was 2.74 spores/g soil in Exotic; 5.17 spores/g soil in Native; 1.16 spores/g soil in Invasive1; and 0.86 spores/g soil in Invasive2. Diversity ( $\mathrm{H}$, Shannon's index) and dominance (C, Simpson's index) in the Exotic and Native was about 2.42 and 0.89 respectively, but in the Invasive1 and Invasive2 these values changed to 1.76 and 0.76 respectively (Tab. 1 ).

Including all studied root zones, 19 different AMF species were identified belonging to eleven genera Acaulospora (2), Claroideoglomus (2), Dentiscutata (2), Entrophospora (1), Funneliformis (2), Gigaspora (3), Glomus (1), Quatunica (1), Racocetra (1), Rhizoglomus (3) and Scutellospora (1) (Tab. 2). Of the total AMF species, 12 (63.15\%) were classified as intermediate species: Acaulospora denticulata, A. tuberculata, Claroideoglomus claroideum, Dentiscutata cerradensis, D. heterograma, Entrophospora infrequens, Gigaspora albida, G. decipiens, G. gigantea, Quatunica erythropus, Rhizoglomus intraradices, and Scutellospora calospora; and 7 (36.85\%) were classified as generalist: Claroideoglomus etunicatum, Funneliformis caledonium, F. geosporum, Glomus multicaule, Racocetra coralloidea, Rhizoglomus aggregatum, and Rhizoglomus clarum. We did not found any AMF species with frequency of occurrence classified as rare (sensu Zhang et al. 2004), or exclusive (sensu Stürmer \& Siqueira 2011) in our study (Tab. 2).

In the Exotic root zone, four AMF species (21.05\%) were classified as Common: C. etunicatum, D. heterograma, F. caledonium, and R. clarum; and 15 AMF species (78.95\%) were classified as Rare: A. denticulata, A. tuberculata, C. claroideum, D. cerradensis, D. erythropus, E. infrequens, F. geosporum, G. albida, G. decipiens, G. gigantea, $R$. aggregatum, $R$. multicaule, $R$. coralloidea, $R$. intraradices, and S. calospora. For the Native root zone, five AMF species (29.41\%) were classified as Common: C. etunicatum, 
Could biological invasion by Cryptostegia madagascariensis alter the composition of the arbuscular mycorrhizal fungal community in semi-arid Brazil?

Table 1. Mean of AMF identified species (IS), number of spores (NS), diversity (H) and dominance index (C) of each site (mean $\pm S D, N=40)$ for each analyzed parameter.

\begin{tabular}{|c|c|c|c|c|c|}
\hline Parameter & Exotic & Native & Invasivel & Invasive2 & LSD \\
\hline IS & $16.80 \pm 0.80$ & $16.00 \pm 0.90$ & $11.70 \pm 1.11$ & $8.50 \pm 1.93$ & 1.13 \\
\hline NS $\left(\mathrm{g} \mathrm{soil}^{-1}\right)$ & $2.74 \pm 0.11$ & $5.17 \pm 1.65$ & $1.16 \pm 0.06$ & $0.86 \pm 0.08$ & 0.59 \\
\hline H & $2.41 \pm 0.08$ & $2.42 \pm 0.07$ & $2.14 \pm 0.11$ & $1.76 \pm 0.08$ & 0.04 \\
\hline C & $0.88 \pm 0.01$ & $0.89 \pm 0.01$ & $0.85 \pm 0.02$ & $0.76 \pm 0.02$ & 0.05 \\
\hline
\end{tabular}

Table 2. Frequency of occurrence $\left(F O_{i}\right)$ of AMF species of each studied rhizosphere soil

\begin{tabular}{|c|c|c|c|c|c|}
\hline \multirow{2}{*}{ AMF species } & \multicolumn{4}{|c|}{$F O^{\prime}$ [classification ${ }^{2}$ ] } & \multirow{2}{*}{ Species classification $^{8}$} \\
\hline & Exotic & Native & Invasivel & Invasive2 & \\
\hline \multicolumn{6}{|l|}{ Order Diversisporales } \\
\hline \multicolumn{6}{|l|}{ Family Acaulosporaceae } \\
\hline Acaulospora denticulata Sieverd. \& S. Toro & $2.9(\mathrm{R})$ & $3.3(\mathrm{R})$ & $3.0(\mathrm{R})$ & - & Intermediate \\
\hline Acaulospora tuberculata Janos \& Trappe & $1.5(\mathrm{R})$ & $1.6(\mathrm{R})$ & $0.8(\mathrm{R})$ & - & Intermediate \\
\hline \multicolumn{6}{|l|}{ Order Gigasporales } \\
\hline \multicolumn{6}{|l|}{ Family Dentiscutataceae } \\
\hline Dentiscutata cerradensis (Spain \& J. Miranda) Sieverd., F.A. Souza \& Oehl & $1.3(\mathrm{R})$ & $2.5(\mathrm{R})$ & $1.1(\mathrm{R})$ & - & Intermediate \\
\hline Dentiscutata heterogama (T.H. Nicolson \& Gerd.) Sieverd., F.A. Souza \& Oehl & $10.2(C)$ & $10.8(C)$ & $1.5(\mathrm{R})$ & - & Intermediate \\
\hline Quatunica erythropus (Koske \& C. Walker) F.A. Souza, Sieverd. \& Oehl & $1.8(\mathrm{R})$ & $1.4(\mathrm{R})$ & $0.4(\mathrm{R})$ & - & Intermediate \\
\hline \multicolumn{6}{|l|}{ Family Gigasporaceae } \\
\hline Gigaspora albida N.C. Schenck \& G.S. Sm. & $0.6(\mathrm{R})$ & $1.2(\mathrm{R})$ & - & - & Intermediate \\
\hline Gigaspora decipiens I.R. Hall \& L.K. Abbott & $1.1(\mathrm{R})$ & $1.6(\mathrm{R})$ & - & - & Intermediate \\
\hline Gigaspora gigantea (T.H. Nicolson \& Gerd.) Gerd. \& Trappe & $1.1(\mathrm{R})$ & $1.7(\mathrm{R})$ & - & - & Intermediate \\
\hline \multicolumn{6}{|l|}{ Family Racocetraceae } \\
\hline Racocetra coralloidea (Trappe, Gerd. \& I. Ho) Oehl, F.A. Souza \& Sieverd. & $2.1(\mathrm{R})$ & $4.1(\mathrm{R})$ & $4.9(\mathrm{R})$ & $5.9(\mathrm{R})$ & Generalist \\
\hline \multicolumn{6}{|l|}{ Family Scutellosporaceae } \\
\hline Scutellospora calospora (T.H. Nicolson \& Gerd.) C. Walker \& F.E. Sanders & $1.7(\mathrm{R})$ & $2.4(\mathrm{R})$ & - & - & Intermediate \\
\hline \multicolumn{6}{|l|}{ Order Glomerales } \\
\hline \multicolumn{6}{|l|}{ Family Entrophosporaceae } \\
\hline Entrophospora infrequens (I.R. Hall) R.N. Ames \& R.W. Schneider & $1.7(\mathrm{R})$ & $1.7(\mathrm{R})$ & - & - & Intermediate \\
\hline Claroideoglomus claroideum (N.C. Schenck \& G.S. Sm.) C. Walker \& Schüßler & $2.4(\mathrm{R})$ & - & $8.9(\mathrm{R})$ & $6.9(\mathrm{R})$ & Intermediate \\
\hline Claroideoglomus etunicatum (W.C. Becker \& Gerd.) C. Walker \& Schüßler & $15.5(\mathrm{C})$ & $16.0(\mathrm{C})$ & $14.9(C)$ & $5.2(\mathrm{R})$ & Generalist \\
\hline \multicolumn{6}{|l|}{ Family Glomeraceae } \\
\hline Funneliformis caledonium (T.H. Nicolson \& Gerd.) C. Walker \& Schüßler & $14.2(C)$ & $14.5(C)$ & $9.5(\mathrm{R})$ & $6.9(\mathrm{R})$ & Generalist \\
\hline Funneliformis geosporum (T.H. Nicolson \& Gerd.) C. Walker \& Schüßler & $10.0(\mathrm{R})$ & $10.1(C)$ & $7.7(\mathrm{R})$ & $4.5(\mathrm{R})$ & Generalist \\
\hline Glomus multicaule Gerdemann \& B.K. Bakshi & $6.3(\mathrm{R})$ & $6.6(\mathrm{R})$ & $2.8(\mathrm{R})$ & $2.6(\mathrm{R})$ & Generalist \\
\hline Rhizoglomus aggregatum (N.C. Schenck \& G.S. Sm.) Sieverd., G.A. Silva \& Oehl & $3.5(\mathrm{R})$ & $5.1(\mathrm{R})$ & $5.8(\mathrm{R})$ & $7.9(\mathrm{R})$ & Generalist \\
\hline Rhizoglomus clarum (T.H. Nicolson \& N.C. Schenck) Sieverd., G.A. Silva \& Oehl & $15.5(\mathrm{C})$ & $15.5(C)$ & $11.1(C)$ & $7.5(\mathrm{R})$ & Generalist \\
\hline Rhizoglomus intraradices (N.C. Schenck \& G.S. Sm.) Sieverd., G.A. Silva \& Oehl & $6.4(\mathrm{R})$ & - & $27.7(C)$ & $52.7(\mathrm{D})$ & Intermediate \\
\hline
\end{tabular}

${ }^{1} \mathrm{FO}_{i}=\mathrm{n}_{\mathrm{i}} / \mathrm{N}$, where $\mathrm{n}_{\mathrm{i}}$ is the number of times an AMF species was observed and $\mathrm{N}$ is the total of AMF spores observed from each studied condition; ${ }^{2} \mathrm{Classification}$ of AMF frequency of occurrence proposed by Zhang et al. (2004): $\mathrm{R}$ - rare (FO < 10\%); $\mathrm{C}$ - common $(10 \leq \mathrm{FO} \leq 30 \%)$; $\mathrm{MC}-\operatorname{most}$ common $(31 \leq \mathrm{FO} \leq 50)$; and $\mathrm{D}$ - dominant (FO > $50 \%$ ); ${ }^{3}$ Species classification proposed by Stürmer and Siqueira (2011): generalists (present in all areas), intermediate (present in 2 or 3 areas) or exclusive (present in only one area). 
F. caledonium, D. heterograma, F. geosporum, and R. clarum; and 12 AMF species (70.59\%) were classified as Rare: A. denticulata, A. tuberculata, D. cerradensis, E. infrequens, G. albida, G. decipiens, G. gigantea, G. multicaule, Q. erythropus, $R$. aggregatum, $R$. coralloidea, and $S$. calospora (Tab. 2).

In the Invasive1, three AMF species (21.42\%) were classified as Common: C. etunicatum, R. clarum and $R$. intraradices; and 11 AMF species (78.58\%) were classified as Rare: A. denticulata, A. tuberculata, C. claroideum, Dentiscutata cerradensis, D. heterograma, F. caledonium, F. geosporum, G. multicaule, Q. erythropus, R. aggregatum, and $R$. coralloidea. $R$. intraradices was the only dominant AMF species (11.2\%) recorded in the Invasive2. Eight AMF species were classified as Rare: $C$. claroideum, C. etunicatum, F. caledonium, F. geosporum, G. multicaule, R. aggregatum, $R$. coralloidea and R. clarum (Tab. 2).

Soil $\mathrm{pH}$, total organic carbon, total nitrogen and available phosphorous were higher in the Invasive 2 than other studied root zones, but no significant differences were observed between Exotic and Native root zones for any of the soil properties analyzed (Tab. 3).

\section{Bioassay}

The AMF inoculation effect on $C$. madagascariensis plant dry biomass varied among the AMF inoculation treatment $\left(F_{5,179}=8.74, p<0.0001\right)$. Native had no differences with control on plant dry biomass, whereas Rhi, Invasive2, Invasive1 and Exotic had a significant positive effect (Tukey's post-hoc test, $\mathrm{p}<0.05$ ). The plant dry biomass decreased in the following order: Rhi > Invasive2 > Invasive1 $=$ Exotic $>$ Control $=$ Native (Fig. 1 ).

There were significant effects of AMF inoculation on the root colonization $\left(F_{4,149}=89.67, p<0.0001\right)$. No differences were found between Rhi, Invasive2, Invasive1, and Exotic treatments, but when compared with the

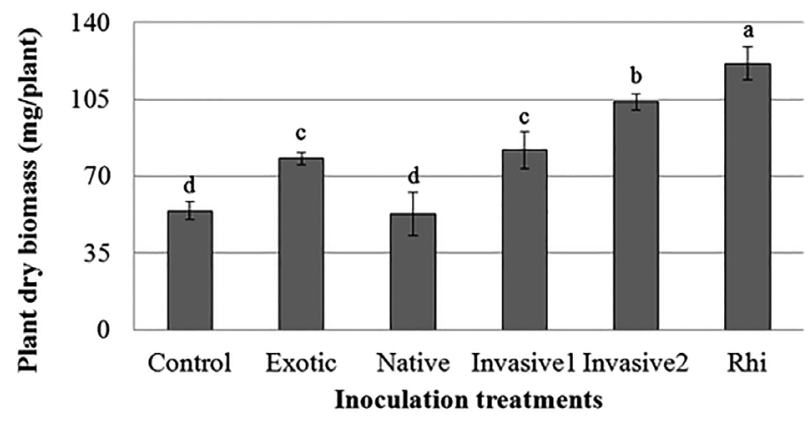

Figure 1. Plant dry biomass (mg plant ${ }^{-1}$ ) in each inoculation treatment (mean $\pm \mathrm{SE}, \mathrm{N}=30$ ), Control = non-inoculation; Exotic = Inoculation with AMF from C. madagascariensis root zone; Native = Inoculation with $\mathrm{AMF}$ from C. prunifera root zone; Invasive1 = Inoculation with AMF from Invasive1 root zone; Invasive 2 = Inoculation with AMF from Invasive2 root zone; Rhi = Inoculation with Rhizoglomus intraradices. Different letters mean significant differences (Tukey's HSD post hoc tests after one-way ANOVA).
Native results, these treatments significantly enhanced the root colonization of $C$. madagascariensis plants. We did not found any AMF colonization structure inside of roots from control, so we excluded it from the statistical analyses (Fig. 2).

The AMF inoculation significantly influenced plant $\mathrm{P}$ content $\left(F_{5,179}=13.62, p<0.0001\right)$. The inoculation with AMF community from Native root zone had lower plant $\mathrm{P}$ content than other five treatments. C. madagascariensis plants had more plant $\mathrm{P}$ content when growing with $\mathrm{AMF}$ inoculum from Invasive 2 root zone, but the exotic plant also experienced positive effects growing with Rhi, Invasive1, and Exotic (Fig. 3).

Differences in AMF inoculation treatments were also detected in PRM $\left(F_{4,149}=4.59, p<0.001\right)$ and $\operatorname{IEP}\left(F_{4,149}=\right.$ $4.59, p<0.001$ ). Plant growth responses (in terms of the plant responsiveness to mycorrhizas and inoculum effect on $\mathrm{P}$ uptake) of the $C$. madagascariensis plants to AMF

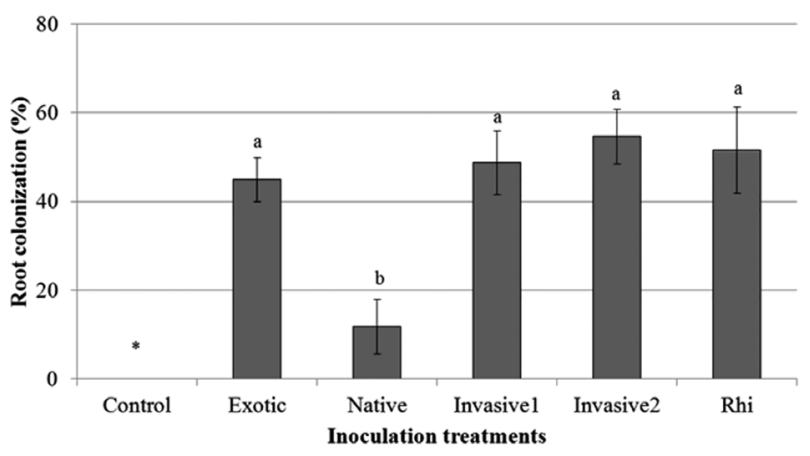

Figure 2. Root colonization (\%) in each inoculation treatment (mean $\pm S E$, $\mathrm{N}=30$ ), Exotic = Inoculation with AMF from $C$. madagascariensis root zone; Native = Inoculation with AMF from $C$. prunifera root zone; Invasive1 = Inoculation with AMF from Invasive1 root zone; Invasive2 = Inoculation with AMF from Invasive2 root zone; Rhi = Inoculation with Rhizoglomus intraradices. Different letters mean significant differences (Tukey's HSD post hoc tests after one-way ANOVA).

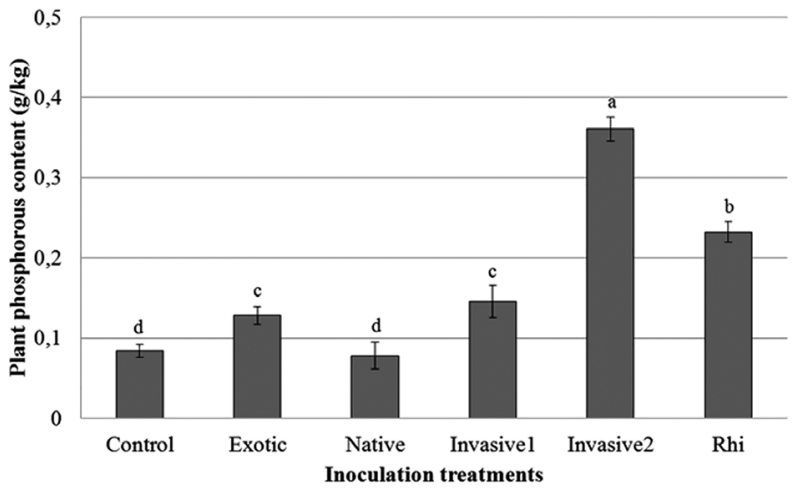

Figure 3. Plant phosphorus content $\left(\mathrm{mg} \mathrm{kg}^{-1}\right)$ in each inoculation treatment (mean $\pm \mathrm{SE}, \mathrm{N}=30$ ), Control = non-inoculation; Exotic = Inoculation with AMF from $C$. madagascariensis root zone; Native = Inoculation with AMF from $C$. prunifera root zone; Invasive1 = Inoculation with AMF from Invasive1 root zone; Invasive2 = Inoculation with AMF from Invasive2 root zone; Rhi = Inoculation with Rhizoglomus intraradices. Different letters mean significant differences (Tukey's HSD post hoc tests after one-way ANOVA). 
inoculation differed among the five treatments and both variables were lowest with AMF from the native root zone (Figs. 4-5). Analyzing the effects of other AMF inoculation treatments we found positive effects on PRM and EIP of C. madagascariensis plants growing in the Rhi, Invasive2, Invasive1 and Exotic inoculation treatments.

\section{Discussion}

The study of field samples shows that the biological invasion by C. madagascariensis changes AMF community composition (Tabs. 1-2) and soil properties (Tab. 3) along the different studied stages of biological invasion in the Brazilian semi-arid, supporting our first hypothesis. The results obtained in the bioassays demonstrate that these altered AMF communities, and especially $R$. intraradices, the most abundant species in the invaded area, promote the growth of the invasive $C$. madagascariensis, supporting the remaining original hypothesis of this study.

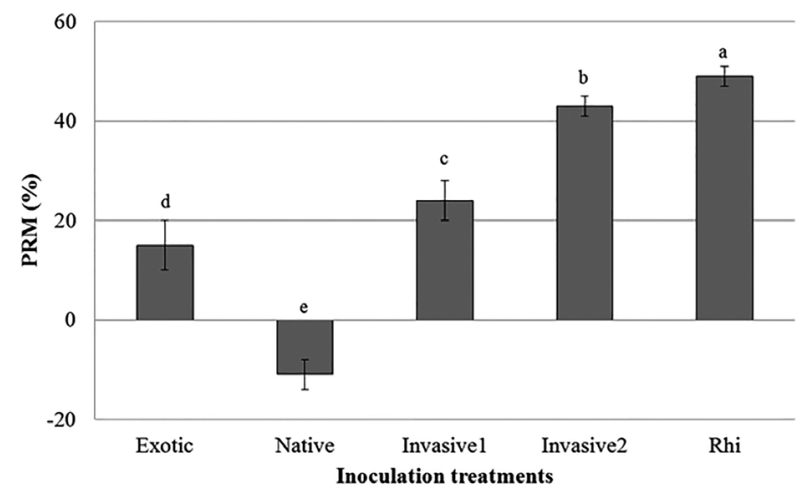

Figure 4. Plant responsiveness to mycorrhiza (PRM \%) in each inoculation treatment (mean $\pm \mathrm{SE}, \mathrm{N}=30$ ), Exotic = Inoculation with $\mathrm{AMF}$ from $C$. madagascariensis root zone; Native = Inoculation with AMF from $C$. prunifera root zone; Invasive1 = Inoculation with AMF from Invasive1 root zone; Invasive2 = Inoculation with AMF from Invasive 2 root zone; $\mathrm{Rhi}=$ Inoculation with $R$ hizoglomus intraradices. Different letters mean significant differences (Tukey's HSD post hoc tests after one-way ANOVA).

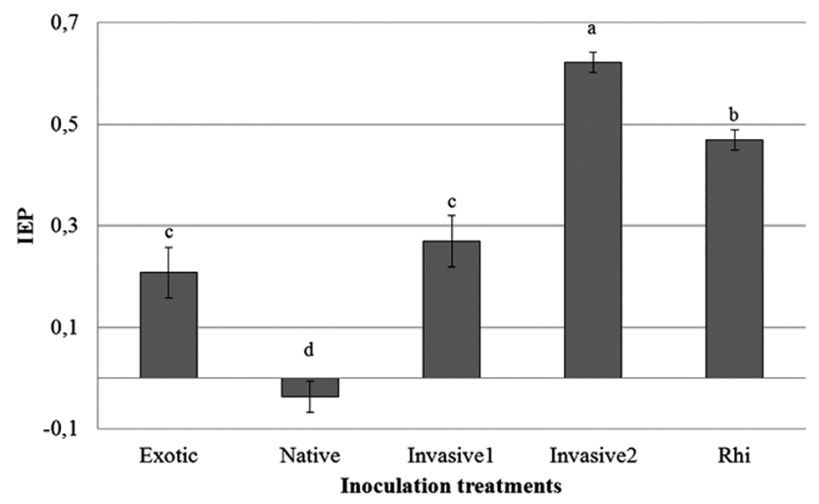

Figure 5. IEP in each inoculation treatment (mean $\pm S E, N=30)$, Exotic = Inoculation with AMF from C. madagascariensis root zone; Native = Inoculation with AMF from C. prunifera root zone; Invasive1 = Inoculation with AMF from Invasive1 root zone; Invasive2 = Inoculation with AMF from Invasive2 root zone; Rhi = Inoculation with Rhizoglomus intraradices. Different letters mean significant differences (Tukey's HSD post hoc tests after one-way ANOVA).
Table 3. Soil properties of the area of each invasion stage by $C$. madagascariensis (mean $\pm \mathrm{SD}, \mathrm{N}=40$ ) for each analyzed parameter.

\begin{tabular}{|c|c|c|c|c|c|}
\hline Parameter & Exotic & Native & Invasive1 & Invasive2 & LSD \\
\hline $\mathrm{pH}$ & $5.83 \pm 0.13$ & $5.31 \pm 0.53$ & $6.43 \pm 0.21$ & $6.89 \pm 0.15$ & 0.21 \\
\hline $\mathrm{TOC}\left(\mathrm{g} \mathrm{kg}^{-1}\right)$ & $3.30 \pm 0.46$ & $3.25 \pm 0.46$ & $7.46 \pm 1.06$ & $9.21 \pm 0.74$ & 1.12 \\
\hline $\mathrm{N}\left(\mathrm{g} \mathrm{kg}^{-1}\right)$ & $0.10 \pm 0.04$ & $0.10 \pm 0.04$ & $0.60 \pm 0.07$ & $0.70 \pm 0.05$ & 0.11 \\
\hline $\mathrm{P}\left(\mathrm{mg} \mathrm{kg}^{-1}\right)$ & $2.83 \pm 1.06$ & $2.53 \pm 1.04$ & $5.50 \pm 1.42$ & $7.76 \pm 1.11$ & 0.98 \\
\hline
\end{tabular}

AMF sporulation, AMF diversity were higher in the Native root zone compared with the results observed in the root zones from different stages of invasion (Invasive1, Invasive2, Exotic) (Tab. 1). The invader altered the composition of AMF communities promoting species from Order Glomerales (e.g. Rhizoglomus intraradices) at the expense of AMF species from Order Diversisporales (e.g. genus Dentiscutata and Scutellospora) (Tab. 2). Our results about AMF diversity and dominance agree with the work done by Oehl et al. (2010) that studied the dynamics of AMF sporulation and found that the AMF community was more diverse in natural fields and with other studies on invasive exotic plants (Hawkes et al. 2006). The presence of $C$. madagascariensis changed AMF composition in roots of $C$. prunifera along the invasion gradient, and when coexisting with the native species, the invader was able to kill the palm tree during its growth, changing the abundance of spores, and AMF diversity (Tab. 1), and the frequency of occurrence of different AMF species, like Acaulospora, Dentiscutata, Entrophospora, Gigaspora, and Scutellospora genus (Tab. 2)

The invasion also altered the values for soil $\mathrm{pH}$, total organic carbon, total nitrogen, and available phosphorous in the root zone (Tab. 3). AMF species from Order Diversisporales (genus Acaulospora), and Gigasporales (genus Dentiscutata, Gigaspora, and Scutellospora) are common in semi-arid sites (Dandan \& Zhiwei 2007; Silva et al. 2014), and in acid soil with low phosphorous availability (Ramos et al. 2008). However, disturbances and changes in soil properties, such as soil $\mathrm{pH}$, total organic carbon and available phosphorous can be favorable for Glomerales species (Oehl et al. 2010; Jansa et al. 2014; Carneiro et al. 2015). Therefore, changes in soil properties induced by the invasive plant may contribute to constrain the occurrence of some AMF species, reduce AMF sporulation, and decrease AMF diversity and AMF dominance (Tab. 1). Silva et al. (2014) in a study performed in an environmental gradient in the Brazilian semi-arid showed a strong correlation of AMF community composition with soil attributes and soil properties are influenced by plant community on a local scale, affecting the community structure even in areas that are geographically close. In our study, the presence of high density of $C$. prunifera dead roots might have stimulate the sporulation specific AMF species and might accelerate chemicals processes in the rhizosphere soil that changed 
the soil properties, like soil $\mathrm{pH}$, total organic carbon, total nitrogen and available phosphorous (Tab. 3).

Studies also showed that plant neighbors were important in structuring AMF communities (Hausmann \& Hawkes 2009), the presence of invasive plants changed AMF composition in roots of their native neighbors (Hawkes et al. 2006), and soil properties also can have influence on the AMF community composition (Oehl et al. 2010; Jansa et al. 2014; Silva et al. 2014).

In our bioassay, all inoculation treatments were capable of root colonization of $C$. madagascariensis plants. Plant dry biomass and root colonization (Figs. 1-2), indicated that the host-plant responded differently to the six AMF treatments. The results from these two variables also indicated a significant responsiveness (around $52 \%$ ) of $C$. madagascariensis to Rhizoglomus intraradices inoculation. In fact, we found a positive effect of Rhizoglomus intraradices in the invasive plant, which might promote the success of the invader (Figs. 4-5).

Prior studies have shown that invasive plants can alter AMF-plants mutualisms (Stinson et al. 2006; Callaway et al. 2008; Seifert et al. 2009 Vogelsang \& Bever 2009). In our study, we found that the inoculation with AMF communities from invaded soils and with $R$. intraradices resulted in a higher plant dry biomass (Control $<$ Native $<$ Exotic $=$ Invasive $1<$ Invasive $2<\mathrm{Rhi}$ ), root colonization (Native $<$ Exotic $=$ Invasive1 $=$ Rhi $=$ Invasive2) $($ Fig. 3 ), and phosphorous uptake $($ Native $<$ Control $<$ Exotic $=$ Invasive 1 $<$ Invasive2 < Rhi) (Fig. 4) than inoculation with native AMF community from $C$. prunifera rhizosphere.

Our work increases the understanding of the ecological mechanisms underlying how exotic species can alter the AMF community composition in field conditions; and how modified AMF communities can affect the growth of the invader. Invaders can encounter certain AMF species that can facilitate their establishment in new environments (Reinhart \& Callaway 2006; CMR Pereira et al. 2014) or the invader can alter AMF composition so as to reduce native species' competitiveness (Vogelsang \& Bever 2009; Stinson et al. 2006). Our results indicate that, under field conditions, C. madagascariensis can change important AMF species either due to a direct preference for some AMF species or indirectly by changes in soil properties. This shift in the AMF community generates positive feedback with the invasive plant as demonstrated in the bioassay experiment. Based on these results, we suggest that the strategy used by $C$. madagascariensis to occupy new environments is to increase the abundance of Rhizoglomus intraradices which in turn has a highly positive effect on the invader's growth.

\section{References}

Agrawal AA, Kotanen PM, Mitchell CE, Power AG, Godsoe W, Klironomos J. 2005. Enemy release? An experiment with congeneric plant pairs and diverse above- and belowground enemies. Ecology 86: 2979-2989.
Alguacil MM, Torrecillas E, Roldán A, Díaz G, Torres MP. 2012. Perennial plant species from semiarid gypsum soils support higher AMF diversity in roots than the annual Bromus rubens. Soil Biology and Biochemistry 49: 132-138.

Alves JJA, Araújo MA, Nascimento SS. 2009. Degradação da Caatinga: uma investigação ecofisiográfica. Revista Caatinga 22: 126-135.

Armas C, Ordiales R, Pugnaire F. 2005. Measuring plant interactions: a new comparative index. Ecology 85: 2682-2886.

Beauregard MS, Gauthier MP, Hamel C, et al. 2013. Various forms of organic and inorganic $P$ fertilizers did no negatively affect soil- and root-inhabiting AM fungi in a maize-soybean rotation system. Mycorrhiza 23: 143-154.

Black CA. 1965. Methods of soil analysis, Part 2. In: Black CA. (ed.) Agronomy monograph No 9. Madison, American Society of Agronomy. p. 771-1572.

Blumenthal D. 2005. Interrelated causes of plant invasion. Science 310: 243-244.

Caifa AN, Martins FR. 2007. Taxonomic identification, sampling methods, and minimum size of the tree sampled: implications and perspectives for studies in the Brazilian Atlantic Rainforest. Functional Ecosystems and Communities 1: 95-104.

Callaway RM, Cipolini D, Barto K, et al. 2008. Novel weapons: invasive plant suppresses fungal mutualists in American but not in its native Europe. Ecology 89: 1043-1055.

Carneiro MAC, Ferreira DA, Souza ED, Paulino HB, Saggin Junior OJ, Siqueira JO. 2015. Arbuscular mycorrhizal fungi in soil aggregates from fields of "murundus" converted to agriculture. Pesquisa Agropecuária Brasileira 50: 313-321.

Costa IR, Araújo FS. 2007. Organização comunitária de um encrave de cerrado sensu stricto no bioma Caatinga, chapada do Araripe, Barbalha, Ceará. Acta Botanica Brasilica 18: 759-770.

Dandan Z, Zhiwei Z. 2007. Biodiversity of arbuscular mycorrhizal fungi in the hot-dry valley of the Jinsha river, southwest China. Applied Soil Ecology 37: 118-128.

Daubenmire RE. 1968. Plant communities: a textbook of plant synecology. New York, Haper and Row.

Durigan G. 2009. Estrutura e diversidade de comunidades florestais. In: Martins SV. (ed.) Ecologia de florestas tropicais do Brasil. Viçosa, Editora UFV. p. 185-215.

Fortin M, Dale MR. 2005. Spatial analysis: a guide for ecologists. Cambridge, Cambridge University Press.

Geel M, Ceustermans A, Hemelrijek W, Lievens B, Hannay O. 2015. Decrease in diversity and changes in community composition of arbuscular mycorrhizal fungi in roots of apple trees with increasing orchard management intensity across a regional scale. Molecular Ecology 24: 941-952.

Gerdemann JW, Nicolson TH. 1963. Spores of mycorrhizal Endogone species extracted from soil by wet sieving and decanting. Transactions of the British Mycological Society 1: 43-66.

Giovannetti M, Mosse B. 1980. An evaluation of techniques for measuring vesicular-arbuscular mycorrhizal infection in roots. New Phytologist 84: 489-500.

Goto BT, Silva GA, Assis DMA, et al. 2012. Intraornatosporaceae (Gigasporales), a new family with two new genera and two new species. Mycotaxon 119: 117-132.

Grümberg BC, Urcelay C, Shroider MA, Vargas-Gil S, Luna CM. 2015. The role of inoculum identity in drought stress mitigation by arbuscular mycorrhizal fungi in soybean. Biology Fertility of Soils 51: 1-10.

Habte M, Osorio NW. 2001. Arbuscular Mycorrhizas: Producing and Applying Arbuscular Mycorrhizal Inoculum. Honolulu, University of Hawaii.

Hausmann NT, Hawkes CV. 2009. Plant neighborhood control of arbuscular mycorrhizal community composition. New Phytologist 183: $1188-1200$

Hawkes CV, Belnap J, D’Antonio C, Firestone MK. 2006. Arbuscular mycorrhizal assemblages in native plant roots change in the presence of invasive exotic grasses. Plant and Soil 281: 369-380.

Heijden MGA, Bardgett RDE, Straalen NM. 2008. The unseen majority: soil microbes as drives of plant diversity and productivity in terrestrial ecosystems. Ecology Letters 11: 296-310. 
Hoagland DR, Arnon DI. 1939. The water culture method for growing plant without soil. California Agricultural Experiment Station, Circular 347:1-32.

Hodge A, Storer K. 2014. Arbuscular mycorrhizal and nitrogen: implications for individual plants through to ecosystems. Plant and Soil 386: 1-19.

Jackson ML. 1973. Estimation of phosphorous content. Soil chemical analysis. New Delhi, Printer Hall Inc.

Janos DP. 2007. Plant responsiveness to mycorrhizas differs from dependence upon mycorrhizas. Mycorrhiza 17: 75-91.

Jansa J, Erb A, Oberholzer HR, Smilauer P, Egli S. 2014. Soil and geography are more important determinants of indigenous arbuscular mycorrhizal communities than management practices in Swiss agricultural soils. Molecular Ecology 23: 2118-2135.

Jenkins WR. 1964. A rapid centrifugal flotation technique for separating nematodes from soil. Plant Disease Reporter 48: 692.

Ji B, Bentivenga SP, Casper BB. 2012. Comparisons of AM fungal spore communities with the same hosts but different soil chemistries over local and geographic scales. Oecologia 168: 187-197.

Johnstone IM. 1986. Plant invasion windows: a time-based classification of invasion potential. Biological Reviews 61: 369-394.

Klironomos JN. 2003. Variation in plant response to native and exotic arbuscular mycorrhizal fungi. Ecology 84: 2292-2301.

Kovach WL. 2007. MVSP - A MultiVariate Statistical Package for windows, ver. 3.1. Pentraeth, Kovach Computing Services.

Kulmatiski A, Kardol P. 2008 Getting plant-soil feedbacks out of the greenhouse: experimental and conceptual approaches. In: Lüttge U, Beyschlag W, Murata J. (eds.) Progress in Botany 69. Berlin, Heidelberg, Springer-Verlag. p. 449-472.

Lekberg Y, Gibbons SM, Rosendahl S, Ramsey PW. 2013. Severe plant invasions can increase mycorrhizal fungal abundance and diversity. ISME Journal 7: 1424-1433.

Mummey DL, Rillig MC. 2006. The invasive plant species Centaurea maculosa alters arbuscular mycorrhizal fungal communities in the field. Plant and Soil 288: 81-90.

Oehl F, Laczko E, Bogenrieder A, et al. 2010. Soil type and land use intensity determine the composition of arbuscular mycorrhizal fungal communities. Soil Biology and Biochemistry 42: 724-738.

Oehl F, Souza FA, Sieverding E. 2008. Revision of Scutellospora and description of five new genera and three new families in the arbuscular mycorrhiza-forming Glomeromycetes. Mycotaxon 106: 311-360.

Oehl F, Sieverding E, Palenzuela J, Ineichen K, Silva GA. 2011. Advances in Glomeromycota taxonomy and classification. IMA Fungus 2: 191-199.

Okalebo JR, Gathua KW, Woomer PL. 1993. Laboratory Methods of Plant and Soil Analysis: A Working Manual. Technical Bulletin No. 1 Soil Science Society East Africa.

Olsen SR, Cole CV, Watanable FS, Dean LA. 1954. Estimation of available phosphorous in soils by extraction with Sodium bicarbonate. Washigton, US Department of Agriculture, (Circular 939).

Ortiz N, Armada E, Duque E, Roldán A, Azcón A. 2015. Contribution of arbuscular mycorrhizal fungi and/or bacteria to enhancing plant drought tolerance under natural soil conditions: Effectiveness of autochthonous or allochthnous strains. Journal of Plant Physiology 174: 87-96.

Parkash V, Aggarwal A. 2009. Diversity of endomycorrhizal fungi and their synergistic effect on the growth of Acacia catechu Willd. Journal of Forest Science 55: 461-468.

Pereira DS, Sousa JES, Pereira MS, Gonçalves NR, Bezerra AME. 2014. Emergence and initial growth of Copernicia prunifera (Arecaceae) as a function of fruit maturation. Journal of Seed Science 36: 9-14.

Pereira CMR, Silva DKA, Ferreira ACA, Goto BT, Maia LC. 2014. Diversity of arbuscular mycorrhizal fungi in Atlantic forest areas under different land uses. Agriculture, Ecosystems and Environment 185: 245-252.

Phillips JM, Hayman DS. 1970. Improved procedures for clearing roots and staining parasitic and vesicular-arbuscular mycorrhizal fungi for rapid assessment of infection. Transactions of the British Mycological Society 55: 158-160.

Ramos AC, Façanha AR, Feijó JA. 2008. Proton $\left(\mathrm{H}^{+}\right)$flux signature for the presymbiotic development of the arbuscular mycorrhizal fungi. New Phytologist 178: 177-188.

Reinhart KO, Callaway RM. 2006. Soil biota and invasive plants. New Phytologist 170: 445-457.

Richardson DM, Allsopp N, D’Antonio CM, Milton SJ, Rejmánek M. 2000. Plant invasions-the role of mutualisms. Biological Reviews 75: 65-93.

Rodríguez-Echeverría S, Crisóstomo JA, Nabais C, Freitas H. 2009. Belowground mutualisms and the invasive ability of Acacia longifolia in coastal dunes of Portugal. Biological invasions 11: 651-661.

Schenck NC, Perez Y. 1990. Manual for the Identification of VA Mycorrhizal Fungi. 2nd edn. International Culture Collection of VA Mycorrhizal Fungi (INVAM). Gainesville, University of Florida.

Seifert EK, Bever JD, Maron JL. 2009. Evidence for the evolution of reduced mycorrhizal dependence during plant invasion. Ecology 90: 1055-1062.

Shannon CE, Weaver W. 1949. The mathematical theory of communication. Urbana, University of Illinois Press.

Sieverding E, Silva GA, Berndt R, Oehl F. 2014. Rhizoglomus, a new genus of the Glomeraceae. Mycotaxon 129: 373-386.

Silva IRS, Mello CMA, Ferreira Neto RA, et al. 2014. Diversity of arbuscular mycorrhizal fungi along an environmental gradient in the Brazilian semiarid. Applied Soil Ecology 84: 166-175.

Silva JL, Barreto RW, Pereita OL. 2008. Pseudocercospora cryptostegiaemadagascariensis sp. nov. on Cryptostegia madagascariensis, an exotic vine involved in major biological invasion in Northeast Brazil. Mycopathologia. 166: 87-91.

Simpson EH. 1949. Measurement of diversity. Nature 163: 688.

Smith SE, Read DJ. 2008. Mycorrhizal symbiosis. London, Academic Press and Elsevier.

Sousa LA, Guimarães LL, Reis AT, et al. 2013. Crescimento da fito invasora Cryptostegia madagascariensis submetida a estresse salino. http://www.unicap.br/simcbio/wp-content/uploads/2014/09/ CRESCIMENTO-DA-FITO-INVASORA-Cryptostegia-madagascariensis-SUBMETIDA-A-ESTRESSE-SALINO.pdf. 02 Jan. 2015.

Stampe ED, Daehler CC. 2003. Mycorrhizal species identity affects plant community structure and invasion: a microcosm study. Oikos 100: 362-372.

Stinson KA, Campbell SA, Powell JR, et al. 2006. Invasive plant suppresses the growth of native tree seedlings by disrupting belowground $\mathrm{mu}-$ tualisms. PLoS Biology 4: e140 doi:10.1371/journal.pbio.0040140.

Stürmer SL, Siqueira JO. 2011. Species richness and spore abundance of arbuscular mycorrhizal fungi across distinct land uses in Western Brazilian Amazon. Mycorrhiza 21: 255-267.

Vogelsang KM, Bever JD. 2009. Mycorrhizal densities decline in association with nonnative plants and contribute to plant invasion. Ecology 90: 399-407.

Walker C, Vestberg M, Demircik F, et al. 2007. Molecular phylogeny and new taxa in the Archaeosporales (Glomeromycota): Ambispora fennica gen. sp. nov., Ambisporaceae fam. nov., and emendation of Archaeospora and Archaeosporaceae. Mycological Research 111: 137-153.

Wang P, Wang Y, Shu B, Liu J, Xia R. 2015. Relationships between arbuscular mycorrhizal symbiosis and soil fertility factors in Citrus Orchards along an altitudinal gradient. Pedosphere 25: 160-168.

WRB - IUSS working group. 2006. World reference base for soil. World soil resources reports. n. 103. Rome, FAO.

Zar JH. 1984. Biostatistical analysis. New Jersey, Prentice Hall.

Zhang Y, Gui LD, Liu RJ. 2004. Survey of arbuscular mycorrhizal fungi in deforested and natural forest land in the subtropical region of Dujiangyan, southwest China. Plant and Soil. 261: 257-263.

Zhang Q, Yang R, Tang J, Yang H, Hu S, Chen X. 2010. Positive feedback between mycorrhizal fungi and plants influences plant invasion success and resistance to invasion. PLoS ONE 5: e12380. doi: 10.1371/ journal.pone.0012380. 